\title{
PENERAPAN ASERTIVE BEHAVIOR THERAPY DAN POSITIVE REINFORCEMENT UNTUK MENGURANGI KECENDERUNGAN PERILAKU AGRESIVITAS VERBAL PADA ANAK USIA TENGAH
}

\author{
Nashwa Oelfy ${ }^{1}$, Debora Basaria ${ }^{2}$, Samanta Nur Ananta ${ }^{3}$ \\ ${ }^{1}$ Fakultas Psikologi, Universitas Tarumanagara \\ Email: nashwaoelfy@gmail.com \\ ${ }^{2}$ Fakultas Psikologi, Universitas Tarumanagara \\ Email: deborab@fpsi.untar.ac.id \\ ${ }^{3}$ Fakultas Psikologi, Universitas Tarumanagara \\ Email:mantamonik@gmail.com
}

\begin{abstract}
ABSTRAK
Dalam tahap perkembangan, tak jarang anak mengalami hambatan atau bahkan melakukan perilaku yang keliru yang dapat merugikan mereka, baik untuk dirinya sendiri maupun orang lain. Perilaku yang sering terjadi pada anak adalah perilaku agresivitas. Perilaku agresivitas terjadi pada masa perkembangan, karena pada masa inilah seorang anak sudah mulai merasa ingin mengetahui dan ingin melakukan sesuatu yang dia inginkan walaupun tanpa dia sadari sesuatu yang dia lakukan itu dapat berdampak negatif pada dirinya sendiri ataupun pada orang lain. Oleh sebab itu, Assertive Behavior Therapy dan Positive Reinforcement diterapkan pada penelitian ini sebagai upaya untuk mengurangi kecenderungan perilaku agresivitas dari lima anak usia tengah di Panti sosial X. Penelitian ini menggunakan quantitative one group pre-test post-test design dimana alat ukur Agresivitas dianalisa untuk mengetahui perbandingan hasil sebelum dan sesudah pemberian intervensi. Terlihat kelima partisipan mengalami penurunan dari perilaku agresivitasnya. Total skor yang diperoleh kelima partisipan menunjukkan bahwa agresivitas mereka berada dalam kategori sedang. Berdasarkan hasil, dapat disimpulkan bahwa efektivitas dari Assertive Behavior Therapy dan Positive Reinforcement untuk mengurangi kecenderungan perilaku agresivitas verbal dari lima anak usia tengah di Panti sosial X tergolong cukup efektif.
\end{abstract}

Kata kunci: agresivitas verbal, assertive behavior therapy, positive reinforcement, anak usia tengah

\section{PENDAHULUAN}

\section{Latar Belakang}

Anak-anak usia sekolah dasar atau periode anak usia tengah, umumnya berada dalam proses perkembangan yang berlangsung dengan cepat dalam aspek fisik, emosional, intelektual dan sosial. Dalam tahap perkembangan tersebut, tak jarang anak mengalami hambatan atau bahkan melakukan perilaku yang keliru yang dapat merugikan mereka, baik untuk dirinya sendiri maupun orang lain. Perilaku yang dicerminkan dapat berupa perilaku yang positif dan perilaku yang negatif, salah satunya yaitu berupa perilaku kenakalan. Kenakalan pada anak dimaknai sebagai suatu bentuk perilaku yang tidak sesuai dengan norma-norma yang hidup di tengah masyarakat. Pada umumnya, kenakalan merupakan produk konstitusi defektif dari mental dan emosi, yaitu mental dan emosi anak yang belum matang (labil) dan rusak (defektif) sebagai akibat proses pengondisian oleh lingkungan yang buruk (Kartono, 2007).

Siswa di Sekolah Dasar (SD) mengalami masalah-masalah yang berkenaan dengan perkembangan individu, dan perbedaan individu dalam hal kecerdasan, kecakapan, hasil belajar, bakat, sikap, kebiasaan, pengetahuan, kepribadian, cita-cita, kebutuhan, minat, pola-pola, dan tempo perkembangan, ciri-ciri jasmani dan latar belakang lingkungan. Terdapat juga perbedaan kebutuhan individu dalam hal memperoleh kasih sayang, memperoleh harga diri, memperoleh penghargaan yang sama, ingin dikenal, memperoleh prestasi dan posisi, untuk dibutuhkan orang lain, merasa bagian dari kelompok, rasa aman dan perlindungan diri, dan untuk memperoleh 
kemerdekaan diri. Adanya perbedaan penyesuaian diri, yang salah satunya juga mempengaruhi perbedaan tingkah laku. Muncul juga masalah belajar dalam diri anak (Thomas \& Bierman, 2006).

Perilaku yang sering terjadi pada anak adalah perilaku agresivitas. Perilaku agresivitas dapat didefinisikan sebagai perilaku yang terlihat yang dapat mengakibatkan kerugian bagi diri sendiri atau orang lain (Sukhodolsky et al., 2016). Diketahui bahwa anak-anak dengan tingkat agresi yang lebih tinggi memiliki tingkat adaptasi sosial yang lebih rendah daripada anak-anak dengan tingkat agresi yang lebih rendah; dan ada kecenderungan meningkatnya perilaku bermasalah seiring bertambahnya usia anak-anak (Hong \& Rho, 1983; Kim, 2010; dalam Yang-Gyeong et al., 2015). Perilaku agresivitas secara psikologis cenderung menyerang kepada sesuatu yang dipandang sebagai hal yang mengecewakan, menghalangi atau menghambat. Perilaku ini terjadi pada masa perkembangan, karena pada masa inilah seorang anak sudah mulai merasa ingin mengetahui dan ingin melakukan sesuatu yang dia inginkan walaupun tanpa dia sadari sesuatu yang dia lakukan itu dapat berdampak negatif pada dirinya sendiri ataupun pada orang lain (Hurlock, 1987). Perilaku mengganggu anak seperti agresi adalah salah satu alasan paling sering digunakan sebagai rujukan kesehatan mental rawat jalan (dalam Sukhodolsky et a.l, 2016).

Perilaku agresivitas anak muncul manakala anak merasakan adanya ancaman, marah, gusar, atau frustrasi. Perilaku agresivitas sesungguhnya merupakan reaksi normal pada anak-anak yang masih kecil. Anak-anak secara naluriah akan memunculkan perilaku ini ketika mereka merasa tidak nyaman, ketika mereka ingin melindungi diri mereka, atau ketika mereka ingin mencapai suatu tujuan tertentu namun tidak mengetahui bagaimana cara yang lebih baik untuk meraihnya. Selain itu, perilaku agresivitas juga merupakan cara khas anak kecil untuk menunjukkan kepada orang lain bahwa mereka tidak suka pada apa yang dilakukan orang lain terhadap mereka. Akan tetapi, seiring dengan bertambahnya usia mereka, anak-anak seharusnya menjadi semakin mampu menggunakan cara-cara yang lebih tepat untuk meraih tujuannya, sehingga tidak perlu bertindak dengan cara yang agresivitas. Perilaku agresivitas menjadi bagian dari tahapan perkembangan mereka dan sering kali menimbulkan masalah, baik itu di rumah, sekolah ataupun dalam suatu kelembagaan yang mana disuatu tempat tersebut dia dapat berinteraksi terutama dengan orang lain. Diharapkan setelah melewati usia 7 tahun, anak sudah lebih dapat mengendalikan dirinya untuk tidak menyelesaikan masalah dengan perilaku agresivitas. Perilaku agresivitas pada anakanak telah terbukti memiliki kemampuan verbal yang lemah, keterampilan resolusi konflik yang buruk, dan defisit dalam keterampilan pertemanan (Deater-Deckard, 2001; dalam Sukhodolsky, 2016).

Perilaku agresivitas yang menyebabkan sakit fisik (nonverbal) antara lain memukul, menggigit, mencubit, menendang, menginjak, melempari orang dengan benda, dan sebagainya. Sedangkan secara psikis (verbal), diantaranya mengucapkan kata-kata hinaan atau mengejek, memaki dengan kata-kata kotor, melecehkan, mengancam, membentak orang yang lebih tua, atau bahkan memerintah orang lain seenaknya saja. Dengan adanya perubahan baik dari sisi seksual, psikologis maupun sosial membuat masa anak- anak seringkali menjadi masa-masa rawan terjadinya adanya perilaku agresivitas yang diakibatkan kurangnya bimbingan orang tua, kurangnya perhatian guru, pengaruh lingkungan, pergaulan yang tidak baik atau kurangnya perhatian dari orang tua adanya pola asuh anak yang dapat mempengaruhi semua ini (Pohan, 1986).

Figur dan pola asuh orangtua merupakan sosok yang penting dalam menjadi panutan bagi anakanak dalam tahap perkembangan anak. Nilai-nilai moral yang dimiliki orangtua dalam berbagai hal memiliki kemungkinan besar untuk menurun ke anak mereka. Akan tetapi, bagi anak-anak yang tidak memiliki orangtua, ketidakhadiran orangtua dalam tahap perkembangan mereka 
dikhawatirkan memiliki efek negatif. Ketiadaan salah satu sosok yang signifikan sebagai panutan menjadi kemungkinan anak akan mencari sosok panutan lainnya. Meskipun sosok panutan pilihan anak tersebut tidak selamanya akan buruk, tetapi mereka masih sangat minim dalam pengalaman hidup dan kemampuan bermasyarakat. Banyak anak yang berasal dari status sosial-ekonomi yang ke bawah juga dapat menjadi penyebabnya timbulnya perilaku agresivitas (Berg et al., 2011).

Gangguan perilaku agresivitas adalah gangguan umum yang terjadi pada masa anak-anak, tetapi jika perilaku agresivitas dibiarkan, maka akan memberikan dampak negatif pada kehidupan anak di masa mendatang yaitu perilaku kekerasan, kenakalan remaja dan perilaku menyimpang lainnya. Salah satu bentuk intervensi yang efektif dalam mengubah tingkah laku agresivitas adalah dengan melakukan assertive behavior therapy (Semiun, 2006). Dalam intervensi ini anak dilatih untuk bersikap asertif dalam menghadapi berbagai situasi dan diharapkan adanya perubahan perilaku yang lebih positif melalui proses belajar pada anak dari sebelum dengan sesudah latihan dan dapat menurunkan perilaku agresivitas ke perilaku asertif pada diri anak. Cara yang digunakan dalam intervensi ini adalah dengan permainan peran dalam diskusi kelompok dengan bimbingan terapis (Sunardi, 2010).

Assertive behavior therapy termasuk ke dalam terapi behavioral. Menurut Willis (2004) terapi behavioral berasal dari dua arah konsep yakni Ivan Pavlov dan B.F Skinner. Mula-mula terapi ini dikembangkan oleh Wolpe untuk menanggulangi neurosis. Neurosis dapat dijelaskan dengan mempelajari perilaku yang tidak adaptif melalui proses belajar secara langsung. Dengan kata lain perilaku yang menyimpang bersumber atau berasal dari hasil belajar di lingkungan.

Willis (2004) menjelaskan bahwa assertive behavior therapy merupakan terapi behavioral yang menitikberatkan pada kasus yang mengalami kesulitan dalam perasaan yang tidak sesuai dalam menyatakannya. Selain itu Gunarsih (2007), menjelaskan assertive behavior therapy merupakan suatu intervensi yang diberikan kepada klien untuk melatih perilaku penyesuaian sosial melalui ekspresi diri dari perasaan, sikap, harapan, pendapat, dan haknya. Berdasarkan pengertianpengertian tersebut, maka dapat disimpulkan bahwa assertive behavior therapy adalah suatu intervensi yang diberikan untuk membantu peningkatan kepercayaan diri dalam mengkomunikasikan apa yang diinginkan, dirasakan dan dipikirkan pada orang lain namun tetap menjaga dan menghargai hak-hak serta perasaan orang lain, serta mengurangi perilaku agresivitas (Weyns, Verschueren, Leflot et al., 2017).

Intervensi assertive behavior therapy pada kasus kelompok ini juga dibentuk dengan teknik modifikasi perilaku yakni positive reinforcement. Dalam hal ini, behavior modification merupakan bidang psikologi yang berfokus pada menganalisa dan memodifikasi perilaku manusia. Menganalisa berarti mengidentifikasi hubungan fungsional mengenai kejadian di lingkungan dan sebuah perilaku khusus untuk mengerti alasan dari perilaku atau menentukan mengapa seseorang bertindak seperti yang ia lakukan. Modifikasi berarti mengembangkan dan mengimplementasikan prosedur untuk membantu seseorang mengubah perilaku mereka. Modifikasi melibatkan mengubah kejadian di lingkungan untuk mempengaruhi perilaku. Prosedur modifikasi perilaku dikembangkan oleh profesional dan digunakan untuk mengubah perilaku yang signifikan secara sosial, dengan tujuan untuk meningkatkan aspek dari kehidupan seseorang (Miltenberger, 2012). Pemberian positive reinforcement kepada perilaku agresivitas anak dapat mengurangi perilaku agresivitas tersebut secara perlahan (dalam Jung, Krahe \& Busching, 2016).

Modifikasi perilaku dapat digunakan untuk mengurangi perilaku agresivitas individu. Hal ini disebabkan perilaku individu adalah perilaku yang dibentuk, perilaku yang diperoleh, serta 
perilaku yang dipelajari melalui proses belajar (Walgito, 2002). Pengaruh orang lain, penerapan pemberian hadiah dan hukuman merupakan pengaruh penting bagi perilaku seseorang. Menurut Soekadji (1983), modifikasi perilaku merupakan usaha untuk menerapkan prinsip-prinsip proses belajar maupun prinsip-prinsip psikologi hasil eksperimen lain pada manusia. Terdapat beberapa teknik yang dapat diterapkan dalam modifikasi perilaku yaitu peningkatan dan pemeliharaan perilaku, dan pengurangan dan penghapusan perilaku. Berdasarkan beberapa teknik penerapan prinsip belajar, teknik meningkatkan dan memelihara perilaku lebih maju daripada pengurangan dan penghilangan perilaku (Walgito, 2002).

\section{Rumusan Masalah}

Apakah teknik assertive behavior therapy dan positive reinforcement dapat mengurangi kecenderungan perilaku agresivitas verbal pada anak-anak usia tengah?

\section{Tujuan penelitian}

Tujuan dari penelitian ini adalah menerapkan assertive behavior therapy dan positive reinforcement sebagai upaya untuk mengurangi kecenderungan perilaku agresivitas verbal pada anak-anak usia tengah.

\section{METODE PENELITIAN Partisipan penelitian}

Lima anak yaitu T, RZ, W, RK, dan RA yang berpartisipasi dalam penelitian ini memiliki karakteristik sebagai berikut: (a) berada dalam tahapan usia anak tengah, (b) telah mengikuti pembelajaran di Panti sosial X, (c) memperoleh skor intelegensi yang termasuk dalam golongan rata-rata atau di atas rata-rata, dan (d) memperoleh skor agresivitas kategori tinggi pada alat ukur Agresivitas (skor=>98). Kelima anak ini juga diketahui seringkali menampilkan perilaku negatif, yaitu melakukan perilaku agresivitas verbal seperti seringkali mengungkapkan kata-kata kasar (kata umpatan dan nama-nama hewan) kepada teman lainnya di kelas Panti sosial X. Baik kelima anak juga menampilkan perilaku agresivitas verbal kepada adik dan kakak kandungnya. Mereka mengakui bahwa mereka seringkali bertengkar dan beradu mulut dengan saudara-saudara kandungnya. Bahkan, kelima anak juga mengakui bahwa kedua orangtuanya baik masing-masing ibu dan ayahnya kerap menampilkan perilaku mengungkapkan kata-kata kasar (kata umpatan dan nama-nama hewan) kepada anggota keluarga yang juga tinggal di rumah kelima partisipan.

\section{Desain penelitian}

Penelitian ini menggunakan quantitative one group pre-test post-test design dimana kuesioner agresivitas dianalisa untuk mengetahui perbandingan hasil sebelum dan sesudah pemberian intervensi.

\section{Lokasi penelitian}

Pemberian intervensi kelompok pada 5 partisipan ini dilakukan di Panti sosial X-merupakan suatu tempat pembelajaran yang tidak memungut biaya kepada anak-anak didiknya. Pada setiap waktu kegiatan belajar pagi hari berlangsung, yaitu sekitar pukul 08.00-10.00 WIB, kelompok akan diminta untuk melakukan kegiatan bersama dengan pemeriksa.

\section{Instrumen penelitian}

Peralatan yang digunakan dalam penelitian ini meliputi lembar informed consent, alat ukur Agresivitas yang dikembangkan oleh Medinus dan Johnson (1976), alat ukur Culture Fair 
Intelligence Test (CFIT), tes Draw-A-Man (DAM), lembar observasi, lembar wawancara, alat tulis, pohon aturan, kertas A4, spidol berwarma, pensil warna, spidol berwarna dan snacks.

\section{Pengukuran}

Agresivitas digunakan untuk mengukur dependent variable dari penelitian ini, yakni perilaku agresivitas pada anak. Instrumen ini terdiri dari 44 item-item yang menampilkan pernyataanpernyataan berdasarkan variable penelitian itu sendiri yaitu bentuk-bentuk perilaku agresivitas dari skala perilaku agresivitas menurut Medinus dan Johnson (1976). Setiap item memiliki 3 pilihan respons yang harus dipilih berdasarkan perasaan individu $(\mathrm{TP}=$ Tidak Pernah; KK= KadangKadang; $\mathrm{S}=$ Sering).

\section{Prosedur penelitian}

Setelah kelima anak dirujuk oleh pihak Panti sosial X, pre-test untuk mengetahui tingkat perilaku agresivitas mereka dengan mengadministrasikan alat ukur agresivitas. Wawancara autoanamnesa dengan kelima anak dan dengan pihak guru juga dilaksanakan untuk mengetahui gambaran partisipan. Alat ukur agresivitas akan kembali diadministrasikan setelah sesi terakhir dari intervensi yang sudah dilaksanakan (post-test). Hasil pre-test dan post-test kemudian akan dibandingkan untuk mengetahui dampak dari program intervensi terhadap tingkat perilaku agresivitas verbal dari kelima anak.

\section{Pelaksanaan intervensi}

Intervensi assertive behavior therapy dan positive reinforcement yang dijalankan selama 6 sesi. Durasi dari setiap sesi akan berkisar 120 menit. Sesi pertama dilaksanakan pada tanggal 27 November 2017 dan sesi kedua dilaksanakan pada tanggal 29 November 2017. Sesi ketiga dilaksanakan pada tanggal 4 Desember 2017. Sesi keempat dilaksanakan pada tanggal 6 Desember 2017. Sesi kelima dilaksanakan pada tanggal 11 Desember 2017. Sesi keenam dilaksankan pada tanggal 13 Desember 2017. Kegiatan yang dilaksanakan pada tiap sesi didasarkan pada 4 tahapan yang perlu dilakukan dalam assertive behavior therapy dan positive reinforcement, yakni tahap 'Perkenalan dan Warm-Up', 'Recalling Event', 'Emotional Expression dan Issue', dan 'Restitutions' (Rotheram, Bickford, \& Millburn, 2001).

\section{HASIL DAN PEMBAHASAN}

Total skor agresivitas yang diperoleh kelima partisipan sebelum mengikuti intervensi berbeda dengan total skor yang didapat setelah mengikuti 6 sesi intervensi (lihat Tabel 1). Total skor dari kelima anak - T, RZ, W, RK, dan RA, mengalami penurunan. T, yang mendapatkan skor 101 pada pre-test, memperoleh skor 95 pada post-test. RZ, yang mendapatkan skor 99 pada pre-test, memperoleh skor 71 pada post-test. RK, yang mendapatkan skor 99 pada pre-test, memperoleh skor 83 pada post-test. RA, yang mendapatkan skor 99 pada pre-test, memperoleh skor 88 pada post-test. $\mathrm{W}$, yang mendapatkan skor 100 pada pre-test, memperoleh skor 92 pada post-test. Total skor dari kelima anak, baik pada pre-test maupun post-test, mengalami penurunan dari kategori agresivitas tinggi menjadi kategori agresivitas sedang. 
Tabel 1.

Skor Total dan Skor Agresivitas pada Pre-test dan Post-Test

\begin{tabular}{lcccccccccc}
\hline & \multicolumn{2}{c}{ T } & \multicolumn{2}{c}{ RZ } & \multicolumn{2}{c}{ RK } & \multicolumn{2}{c}{ RA } & \multicolumn{2}{c}{$\mathrm{W}$} \\
\hline & Pre- & Post- & Pre- & Post- & Pre- & Post- & Pre- & Post- & Pre- & Post- \\
\hline Agresivitas & 101 & 95 & 99 & 71 & 99 & 83 & 99 & 88 & 100 & 92 \\
\hline Kategorisas & Tingg & Sedan & Tingg & Sedan & Tingg & Sedan & Tingg & Sedan & Tingg & Sedan \\
$\mathrm{i}$ & $\mathrm{i}$ & $\mathrm{g}$ & $\mathrm{i}$ & $\mathrm{g}$ & $\mathrm{i}$ & $\mathrm{g}$ & $\mathrm{i}$ & $\mathrm{g}$ & $\mathrm{i}$ & $\mathrm{g}$ \\
\hline
\end{tabular}

\section{KESIMPULAN, DISKUSI DAN SARAN}

Intervensi kelompok ini dilakukan untuk mengurangi kecenderungan perilaku agresivitas verbal lima anak usia tengah yang merupakan anak didik di Panti sosial X dengan menerapkan assertive behavior therapy dan positive reinforcement. Hasil post-test skala agresivitas menunjukkan bahwa kelima partisipan mengalami penurunan kecenderungan perilaku agresivitas dari kategori perilaku agresivitas tinggi menjadi kategori perilaku agresivitas sedang. Terlihat adanya perubahan signifikan pada setiap hasil yang diperoleh. Berdasarkan hasil ini, dapat disimpulkan bahwa penerapan dari assertive behavior therapy dan positive reinforcement untuk mengurangi kecenderungan perilaku agresivitas verbal dari kelima anak usia tengah di Panti sosial X tergolong cukup efektif.

Adapun beberapa faktor yang mempengaruhi hasil dari assertive behavior therapy positive reinforcement untuk mengurangi kecenderungan perilaku agresivitas verbal pada anak-anak usia tengah diantaranya role-play activities yang disertakan selama sesi berlangsung, jenis intervensi yakni intervensi kelompok, kondisi atau setting lokasi dimana kegiatan dilaksanakan, waktu pelaksanaan di pagi hari, jumlah sesi, serta kehadiran anak-anak didik lain pada keenam sesi. Berbagai aktivitas, termasuk homework, yang memberikan kesempatan pada partisipan untuk mempraktikkan perilaku asertif yang telah dijelaskan, diperagakan dan didiskusikan dapat menghasilkan perubahan

Intervensi kelompok dengan menggunakan pendekatan assertive behavior therapy dan positive reinforcement dapat menurunkan kecenderungan agresivitas verbal pada kelima partisipan, tetapi belum menyeluruh. Penurunan kecenderungan agresivitas verbal dapat terlihat dari hasil tes grafis Draw A Man (DAM) dan kuesioner skala agresivitas. Selain itu, dilengkapi juga dari hasil wawancara terhadap partisipan setelah dilakukannya intervensi. Kelima partisipan menunjukkan penurunan kecenderungan agresivitas verbal, yaitu dengan dihilangkannya gambar gigi dan dengan ekspresi tersenyum. Selain itu, intervensi kelompok ini juga bermanfaat terhadap relasi antara kelima partisipan. Relasi antara kelima partisipan mengalami perubahan ke arah yang lebih positif. Berdasarkan uraian di atas, dapat disimpulkan bahwa manfaat yang diperoleh dari kegiatan intervensi kelompok ini, antara lain partisipan merasa lebih dapat bersikap asertif, melakukan kontrol diri, lebih mengusahakan kontak sosial secara positif dan mengurangi kecenderungan agresi verbal, dan adanya modeling, salah satunya pada partisipan RZ, RK, dan RAyang dapat menahan dirinya dan tidak membalas sehingga sedikit demi sedikit partisipan menampilkan keinginannya untuk berubah ke arah yang lebih positif, yakni bersikap asertif. Selain itu, ada pula feedback yang diperoleh dari group leader dan dari teman-temannya, masing-masing partisipan dapat memperoleh penilaian positif tentang dirinya.

Hasil temuan pada penelitian ini menambah jumlah literatur mengenai assertive behavior therapy dan positive reinforcement pada populasi anak usia tengah di panti sosial yang hingga saat ini masih tergolong terbatas. Meskipun demikian, tidak ada penelitian yang sempurna. Adapun 
beberapa keterbatasan pada penelitian ini adalah tidak adanya control group pembanding serta jumlah sampel yang kecil ( $\mathrm{N}=1$ kelompok). Keterbatasan waktu dan biaya juga menyebabkan tidak diadakannya uji validitas dan reliabilitas untuk alat ukur yang digunakan. Alasan yang serupa juga berakibat pada jumlah sesi yang terbatas serta jarak antar sesi yang inkonsisten.

Saran untuk penelitian selanjutnya. Lima saran yang dapat dipertimbangkan untuk penelitian berikutnya, diantara lain: (a) Rangkaian sesi sebaiknya dilaksanakan dengan jarak antar sesi yang konsisten; (b) Sesi intervensi sebaiknya ditambah untuk meningkatkan jumlah materi yang dapat diberikan dan pembahasan materi secara mendalam kepada partisipan; (c) Pemberian reward kepada partisipan yang dapat menampilkan perilaku asertif. Pemberian reward dapat berupa penambahan hak-hak istimewa kepada masing-masing partisipan, yang sebelumnya perlu adanya diskusi terlebih dahulu antara guru dan partisipan mengenai reward yang diinginkan (token economy); (d) Memperhatikan ruangan yang digunakan untuk intervensi, usahakan menggunakan ruangan yang sesuai dengan kapasitasnya dan juga tidak terlalu banyak barang-barang di dalam ruangan (minim distraksi) atau kesempatan anak-anak panti sosial $\mathrm{X}$ untuk melihat atau bahkan mengganggu, sehingga tidak mengganggu konsentrasi anak dalam melakukan aktivitas.

\section{Ucapan Terima Kasih (Acknowledgement)}

Ucapan terima kasih saya ucapkan kepada pihak Panti sosial X yang telah bersedia meluangkan waktu dalam pengumpulan data, serta bersedia memberikan tempat dan mengizinkan kelima partisipan untuk mengikuti kegiatan intervensi yang dilakukan. Ucapan terima kasih juga saya ucapkan kepada kelima partisipan yang telah bersedia mengikuti seluruh kegiatan di dalam penelitian.

\section{REFERENSI}

Berg, L. K. W., Fingerman, K. L., Smith, J., \& Berg, C. (2011). Handbook of Life-Span Development. New York, NY: Springer Publishing Company, LLC.

Dalyono. (2009). Psikologi Pendidikan. Jakarta: Rineka Cipta.

Gunarsih, S. D. (2007). Konseling dan Psikoterapi. Jakarta: Gunung Mulia.

Hurlock. E. B. (1987). Perkembangan Anak. Jakarta : Erlangga.

Kartono, K. (2007). Perkembangan Psikologi Anak. Jakarta: Erlangga.

Johnson, R. C., \& Medinnus, G. R. (1976). Child Psychology Behavior and Development. New York: John Wiley and Son.

Jung, J., Krahe, B., \& Busching, R. (2016). Beyond the positive reinforcement of aggression: Peers' acceptance of aggression promotes aggression via external control beliefs. International Journal of Behavioral Development, 1-10.

Miltenberger, R. (2012). Behavior modification. California: Wadsworth, Cengage Learning.

Nelson, R., \& Jones. (2006). Human Relationship Skill. New York: Routledge.

Pohan, I. (1986). Masalah Anak Bermasalah. Jakarta: Midas Surya Gratinda.

Purwanta, E. (2005). Modifikasi Perilaku. Jakarta: Departemen Pendidikan tinggi Direktorat Jenderal Pendidikan Tinggi Direktorat Pembinaan Pendidikan Tenaga Kependidikan dan Ketenagaan Perguruan Tinggi.

Rotheram, M. J., Bickford, B., \& Millburn, N. G. (2001). Assertive Behavior Therapy. California: Routledge

Santoso, H. (2005). Disini Matahariku Terbit. Jakarta: Gramedia.

Sukhodolsky, D. G., Smith, S. D., McCauley, S. A., Ibrahim, K., \& Piasecka, J. B. (2016). Behavioral interventions for anger, irritability, and aggression in children and adolescents. Journal of Child and Adolescent Psychopharmacology, 26, 1-7. 
Sattler, J. (2002). Assesment of children: Behavior and clinical applications (4th ed.). San Diego: Jerome M. Sattler..

Sunardi, P. L. B. (2010). Assertive Behavior Therapy. Bandung: FIP UPI

Thomas, D. E., \& Bierman, K. L. The impact of classroom aggression on the development of aggressive behavior problems in children. Dev Psychopathol, 18(2), 471-487.

Walgito, B. (1983). Psikologi Sosial: Suatu Pengantar. Yogyakarta: Yayasan Penerbitan Fakultas Psikologi UGM

Weyns, T., Verschueren, K., Leflot, G., Onghena, P., Wouters, S., \& Colpin, H. (2017). The role of teacher behavior in children's relational aggression development: A five-wave longitudinal study. Journal of School Psychology, 64, 17-27

Willis, S. (2004). Konseling Individual Teori dan Praktek. Bandung: Alfabeta.

Willis, L., \& Daisley, J. (1995). Springboard: Womens Development Workbook. UK: Hawthorn Press

Yang-Gyeong, Y., Duck-Joo, L., In-Soo, L., Namin, S., Ju-Yeon, P., Mi-Ra, Y. R. N., Boas, Y. R. N. (2015). The effects of mind subtraction meditation on depression, social anxiety, aggression, and salivary cortisol levels of elementary school children in south korea. Journal of Pediatric Nursing, 1-13. 